\title{
Access to Sanitation Facilities and Handwashing Practices among Physically Challenged Persons in Homes for the Disabled in Ibadan, Nigeria
}

\author{
Elizabeth 0. Oloruntoba*, Ifiok Pius Udofia, Mumuni Adejumo \\ Department of Environmental Health Sciences, Faculty of Public Health, College of Medicine, University of Ibadan, Ibadan, Nigeria \\ Email: ${ }^{\star}$ li_zzyy@yahoo.com
}

How to cite this paper: Oloruntoba, E.O., Udofia, I.P. and Adejumo, M. (2020) Access to Sanitation Facilities and Handwashing Practices among Physically Challenged Persons in Homes for the Disabled in Ibadan, Nigeria. Journal of Environmental Protection, 11, 299-314.

https://doi.org/10.4236/jep.2020.114017

Received: January 23, 2020

Accepted: April 6, 2020

Published: April 9, 2020

Copyright $\odot 2020$ by author(s) and Scientific Research Publishing Inc. This work is licensed under the Creative Commons Attribution International License (CC BY 4.0). http://creativecommons.org/licenses/by/4.0/

\section{Open Access}

\begin{abstract}
Background: Disabled people in the streets have been adjudged to have the least access to sanitation facilities. Information is inadequate on accessibility to sanitation and hygiene services in homes for the disabled in Nigeria. Purpose: To investigate accessibility to sanitation facilities and handwashing practices among Physically Challenged Persons (PCPs) in selected homes for the disabled in Ibadan. Materials and Methods: Sixty-four consenting PCPs selected from three homes for the disabled in a cross-sectional study were interviewed using questionnaire. Field observation and Focus Group Discussion (FGDs) were conducted using a checklist and FGD guide respectively. Results: Mean age of PCPs was $19.5 \pm 6.8$ years, and $56.2 \%$ were males. All PCPs reported they had water closet toilet-types in their homes, however, $42 \%$ reported that toilet usage was difficult because there were no assistive devices. Observation revealed there were no hand rails or ropes to aid in toilet usage. The FGDs revealed water supply for flushing was inadequate. Although $98.4 \%$ reported handwashing with soap after toilet use, only $54.7 \%$ of the PCPs reported that soap was readily available in their homes/centres. Discussion and Conclusion: Reports by the PCP and field observation showed that there were inadequate assistive devices such as wheelchair ramps, hand rails, or ropes to aid in toilet usage. Sanitation facilities in homes for the disabled should be appropriately built with necessary support to facilitate usage and easy accessibility.
\end{abstract}

\section{Keywords}

Physically Challenged, Sanitation Facilities, Handwashing Practices, Ibadan, Nigeria 


\section{Introduction}

Sanitation services and facilities are traditionally designed for "average" people, ignoring the fact that in our society, people come in a wide range of shapes, sizes, abilities and needs. However, a large number of the "non-average" people are left out of these services and facilities [1]. In a report on disability issues in Nigeria, Dr. Raymond Lang stated that according to estimates by the World Health Organization in 2008 , disabled people make up $20 \%$ of the total population in Nigeria [2]; going by this estimate, there are currently about 39 million disabled people in Nigeria. The disabled people in low to middle income countries have the least access to basic water and sanitation services [1]. According to the $\mathrm{Na}$ tional Demographic Health Survey [3], 43\% of households in Nigeria use improved toilet facilities that are not shared with other households. This implies that other segments of the population are forced to defecate in the open or use unsanitary/shared facilities, with a serious risk of exposure to sanitation-related diseases such as cholera, typhoid, infectious hepatitis, cryptosporidiosis, etc. [4]. Open defecation could be doubly difficult for disabled people, as they experience stigmatization associated with such practice. This could force physically challenged people (particularly women) to restrict themselves to going out in the dark to defecate, with the attendant dangers of accidents, rape and other adverse safety issues, such as attack by animals [1]. Today, the situation does not seem to have improved; the 2017 final JMP report stated that 2.3 billion people lacked basic sanitation service in 2015, and 892 million people worldwide practiced open defecation. At the end of 2015, 17 Sustainable Development Goals (SDGs) were introduced by the United Nations to continue the unfinished business of the 8 Millennium Development Goals (MDGs). The SDG 1 which seeks to "end poverty in all its forms everywhere" by 2030 includes a target for universal access to basic services (e.g. water and sanitation), with a particular focus on the poor and vulnerable groups [5].

However, most of the physically challenged people often become homeless because of poverty and/or shame making them to roam the streets (roadside) as beggars while others end up in homes for the disabled where they are cared for [6]. In order to make disabled people enjoy their right of living peacefully, government established homes for the disabled. These are residential care facilities where special attention is given to disabled persons. These homes provide care and treatment on a short or long term residential basis. It is usually made up of a network of residential facilities providing a function of separating males from females, training and education [7]. Inspite of their increased need for water and sanitation, physically challenged people have restricted access to available facilities because of their physical limitations and inappropriate design of facilities. In a survey on a government run community centre for disabled people in the suburbs of Zambia, Sachelo [8] reported that toilets had no sitting pan and people with impaired lower limbs could not use them. In another study conducted by Tan et al., [9] in Mali, 85\% of persons with disabilities reported 
having to touch the ground while accessing the latrine, indicating accessibility to latrines as a major difficulty they faced. In schools where children use wheelchairs, in the absence of care-givers, the use of a toilet could pose a problem. For instance, a study by Kiwanuka [10] in Uganda concluded that some toilet facilities were too far away from the classroom, hostel or home and most of them lacked wheelchair ramps. Sometimes, physically challenged people found it difficult to use handwashing facilities in the toilets when they finished defecating. This might be attributed to the height of the tap for hand washing being too high for a wheelchair user or someone crawling on the floor. For those crawling, they found the floor too dirty, yet they used bare hands at times when crawling [10].

Nevertheless, access to sanitation facilities is a basic right of all people, including people with disabilities. Studies have shown that disabled people in the streets have the least access to sanitation services, which contributes to their poor health. However there is inadequate information on the level of access to sanitation facilities and handwashing practices by the physically challenged persons in homes for the disabled in Nigeria. This study was designed to investigate accessibility to sanitation facilities and handwashing practices among physically challenged persons in homes for the disabled in Ibadan.

\section{Materials and Methods}

\subsection{Study Area and Locations}

The study was conducted in Ibadan, the capital of Oyo State. Ibadan is located in the south-western part of Nigeria, $128 \mathrm{~km}$ inland northeast of Lagos (the economic hub of the country), and $530 \mathrm{~km}$ southwest of Abuja (the Federal Capital Territory). Ibadan has a total population of 3.16 million, according to the Nigerian Demographics Profile [11]. It has a density of $2140 / \mathrm{sq} \mathrm{mi}\left(828 / \mathrm{km}^{2}\right)$ and a total area of $1190 \mathrm{sq} \mathrm{mi}\left(3080 \mathrm{~km}^{2}\right)$. There are about 15 Homes for the Disabled in Ibadan that are recognised by the Department of Social Welfare. Most of these homes are dominated by the deaf, dumb and mentally retarded, it was observed that the number of persons that used crutches or wheel-chairs was small and so three homes were used for this study. Figure 1 shows the map of the study location, the three homes used for the study are described in Udofia \& Oloruntoba [12].

\subsection{Study Design and Study Population}

This study was cross-sectional in design and involved physically challenged persons from homes for the disabled in Ibadan. The study commenced in February, 2013 and ended in November, 2013. Three (3) homes for the disabled were purposively selected based on the availability of persons with mobility and physical impairments. The selected homes were Sekinat Adekola Centre (SAC), Cheshire Home $(\mathrm{CH})$ for the Disabled; and W.O.Lawal Centre (LC) for the Handicapped. A comprehensive description of the homes is given in Udofia and 


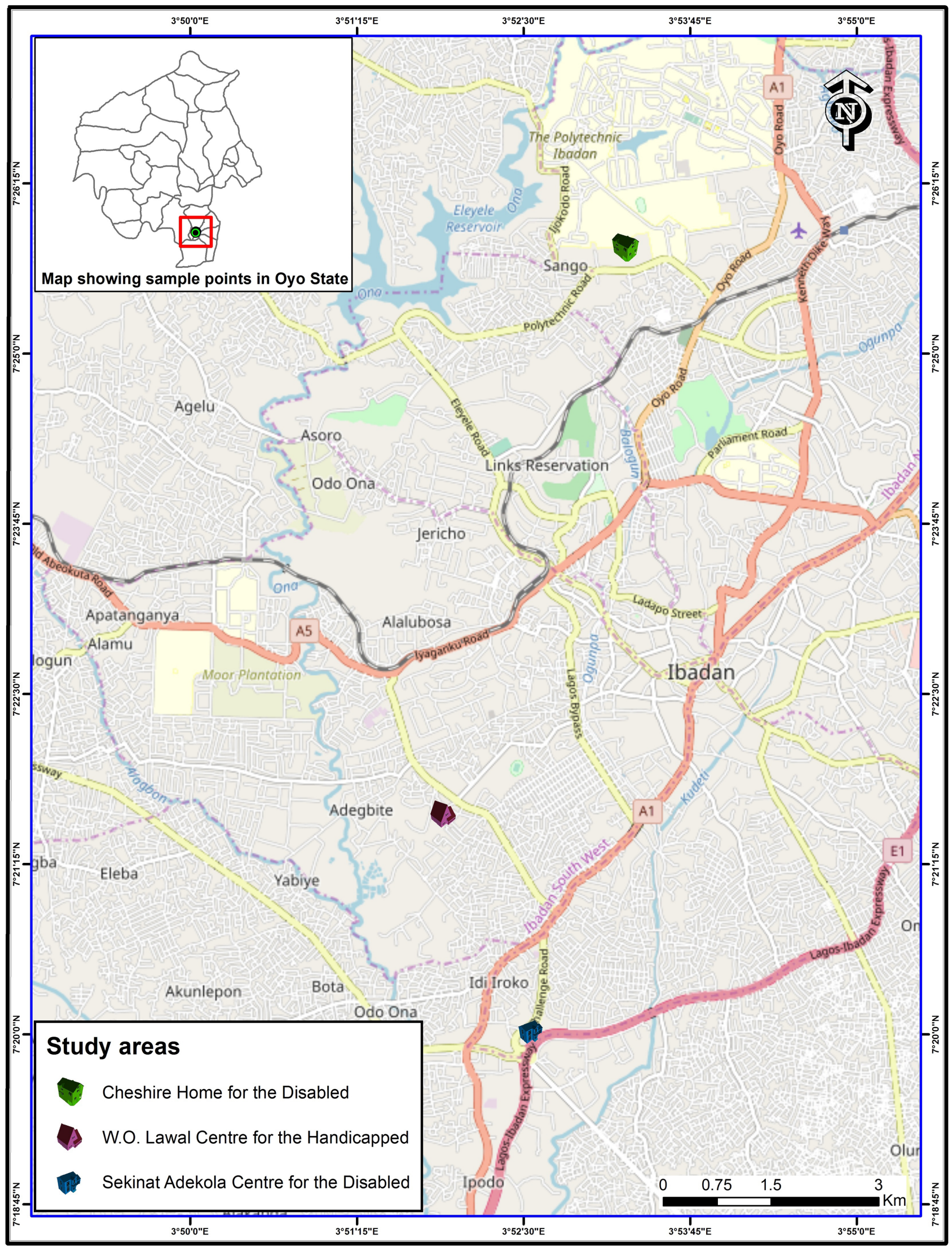

Figure 1. Map of Ibadan showing study areas. 
Oloruntoba [15].

\subsection{Sampling Techniques and Recruitment of Research Assistants}

Sixty-four (64) consenting physically challenged persons from the selected homes (SAC - 11, CH - 35, LC - 18) participated in the study. At the planning stage of the study, the researchers visited the authorities incharge of the homes particularly the head of the homes and social welfare units in-charge of the homes with formal letters to obtain permission to carry out the study in the homes. Also, the study objectives and purpose were explained to the authorities. Furthermore, a formal meeting was held with the physically challenged persons and the teachers in each of the selected homes to give a lecture on the theme and objectives of the study. This was done to ensure that the physically challenged understood all aspects of the study. Permission was granted to carry out the study. Two trained research assistants (male and female) conducted the interviews.

\subsection{Data Collection Procedure}

A semi-structured questionnaire (see appendix) was developed to collect information on demographic characteristics, access to sanitation and hygiene facilites, as well as hygiene practices of the participants; the responses to five (5) questions were used to assess the respondents' handwashing practices. Each question carried 2.5 marks but the fifth question carried 10 marks making a total of 20 marks. The hygiene practice scores were then rated as poor $(0-10)$, fair (11 - 15.5) and good (15.6 - 20). Sanitation facilites were observed using an observational checklist while a Focus Group Discussion guide was used to facilitate discussion among the PCPs on challenges with regards to using available sanitation facilities in the homes.

\subsection{Data Analysis}

Data generated from the field was edited daily and entered into the computer for analyses using Statistical Package for Social Sciences (SPSS) software, version 16.0. Continuous variables were presented as mean and standard deviation while percentages were used to present categorical variable. Chi-square statistic was used to determine the association between demographic characteristics and hygiene practices among the physically challenged. Statistical significance was set at $p \leq 0.05$. Information from the FGDs were analyzed using content analysis and data were presented using thematic approach with verbatim quotations.

\subsection{Ethical Considerations}

The study was approved by the Ethical Review Committee of the Ministry of Health, Oyo State secretariat, Agodi, Ibadan, Nigeria. Consent was obtained from the heads of the respective homes for the disabled and the respondents be- 
fore the commencement of the study. Also, approval and permission were obtained from the social welfare unit in-charge of the homes

\section{Results}

\subsection{Socio-Demographic Characteristics of Respondents}

Socio-demographic characteristics of the disabled persons are presented in $\mathrm{Ta}$ ble 1 . The mean age of the respondents was $19.5 \pm 6.8$ years with a range of $8-$ 38 years.

\subsection{Access to Toilet Facilities}

All the respondents used water closet toilet-type. Due to varying degrees of mobility impairment, it took them different lengths of time to move from their rooms to the toilet (Table 2). A sizeable proportion of the respondents (42\%) reported finding it difficult to use the toilet facility while $30 \%$ said it was manageable. Sixty-four percent of the respondents said there were no structures that aided the usage of the toilet facilities in their respective homes. Observation of

Table 1. Socio-demographic characteristics of the participants.

\begin{tabular}{|c|c|c|}
\hline Socio-demographic characteristics & Frequency & Percentage \\
\hline \multicolumn{3}{|l|}{${ }^{+}$Age (In years) } \\
\hline$\leq 10$ & 6 & 9.4 \\
\hline $11-15$ & 12 & 18.8 \\
\hline $16-20$ & 18 & 28.1 \\
\hline $21-25$ & 13 & 20.3 \\
\hline $26-30$ & 10 & 15.6 \\
\hline$>30$ & 5 & 7.8 \\
\hline \multicolumn{3}{|l|}{ Sex } \\
\hline Males & 36 & 56.2 \\
\hline Females & 28 & 43.8 \\
\hline \multicolumn{3}{|l|}{ Marital Status } \\
\hline Married & 4 & 6.2 \\
\hline Single & 60 & 93.8 \\
\hline \multicolumn{3}{|l|}{ Ethnicity } \\
\hline Yoruba & 52 & 81.2 \\
\hline${ }^{*}$ Others & 12 & 18.8 \\
\hline \multicolumn{3}{|l|}{ Homes } \\
\hline Cheshire & 35 & 54.7 \\
\hline Sekinat Adekola & 11 & 17.2 \\
\hline Lawal Centre & 18 & 28.1 \\
\hline
\end{tabular}

Note: ${ }^{+}=19.5 \pm 6.8$ years $\left(\right.$ Min. $=8$, Max. $=38$ years).${ }^{*}$ Others $=$ Hausa, Igbo, Edo and Fulani. 
Table 2. Accessibility to sanitation facilities.

\begin{tabular}{|c|c|c|c|c|c|}
\hline & & $\begin{array}{c}\text { C.H. } \\
\text { Freq. (\%) }\end{array}$ & $\begin{array}{c}\text { S.A.C. } \\
\text { Freq. (\%) }\end{array}$ & $\begin{array}{c}\text { L.C. } \\
\text { Freq. (\%) }\end{array}$ & $\begin{array}{c}\text { Total } \\
\text { Freq. (\%) }\end{array}$ \\
\hline \multicolumn{6}{|c|}{ Type of toilet facility used in the home } \\
\hline Water closet system & & $35(100)$ & $11(100)$ & $18(100)$ & $64(100)$ \\
\hline Total & & $35(100)$ & $11(100)$ & $18(100)$ & $64(100)$ \\
\hline \multicolumn{6}{|c|}{ Time taken to get to the toilet facility } \\
\hline$\leq 4$ mins & & $23(65.7)$ & $10(90.9)$ & $12(66.7)$ & $45(70.3)$ \\
\hline $5-10$ mins & & $11(31.4)$ & $1(9.1)$ & $5(27.8)$ & $17(26.5)$ \\
\hline $11-16$ mins & & $0(0)$ & $0(0)$ & $1(5.5)$ & $1(1.6)$ \\
\hline$>17$ mins & & $1(2.9)$ & $0(0)$ & $0(0)$ & $1(1.6)$ \\
\hline Total & & $35(100)$ & $11(100)$ & $18(100)$ & $64(100)$ \\
\hline \multicolumn{6}{|c|}{ Best description of usage of the toilet facility } \\
\hline Impossible & & $1(2.9)$ & $1(9.1)$ & $1(5.6)$ & $3(4.7)$ \\
\hline Difficult & & $14(40)$ & $5(45.5)$ & $8(44.4)$ & $27(42.2)$ \\
\hline Manageable & & $12(34.3)$ & $3(27.3)$ & $4(22.2)$ & $19(29.7)$ \\
\hline Convenient & & $8(22.9)$ & $2(18.2)$ & $5(27.8)$ & $15(23.4)$ \\
\hline Total & & $35(100)$ & $11(100)$ & $18(100)$ & $64(100)$ \\
\hline \multicolumn{6}{|c|}{ Availability of structures that make usage easier } \\
\hline \multirow[t]{2}{*}{ Wheelchair ramp } & Yes & $13(37.1)$ & $5(45.5)$ & $5(27.8)$ & $23(35.9)$ \\
\hline & No & $22(62.9)$ & $6(54.5)$ & $13(72.2)$ & $41(64.1)$ \\
\hline Hand rail & No & $35(100.0)$ & $11(100.0)$ & $18(100.0)$ & $64(100.0)$ \\
\hline Ropes & No & $35(100.0)$ & $11(100.0)$ & $18(100.0)$ & $64(100.0)$ \\
\hline
\end{tabular}

the toilet facilities confirmed this as there were no hand rails or ropes to aid the physically challenged during toilet usage, as shown in Figures 2(a)-(c).

It was also observed that the internal space in the toilets was not up to the recommended dimensions of $180 \times 102 \mathrm{~cm}$, as stated by Jones and Reed [1]. In Cheshire Home, the internal space in the male toilet was $170 \times 151 \mathrm{~cm}$ while in the female toilet it was $172 \times 153 \mathrm{~cm}$. In Sekinat Adekola Centre, the internal space in the male toilet was $150 \times 101 \mathrm{~cm}$; in the female toilet, it was $164 \times 124$ $\mathrm{cm}$. In Lawal Centre, the internal space in both the male and female toilets was $120 \times 110 \mathrm{~cm}$. For wheelchair access, the recommended minimum width (of doors) is $80 \mathrm{~cm}$ [1]. In Cheshire Home, the male toilet door width was $86 \mathrm{~cm}$ while that of the female toilet was $80 \mathrm{~cm}$. In Sekinat Adekola Centre, the male toilet door width was $75 \mathrm{~cm}$ while that of the females was $77 \mathrm{~cm}$. In Lawal Centre, the door width for both the male and female toilets was $77 \mathrm{~cm}$. Moreover, observation revealed that most of the hostel structures had no wheelchair ramp for easy movement of disabled people (Figure 2(d)). Furthermore, a high proportion of the physically challenged persons in $\mathrm{CH}(77.1 \%), \mathrm{LC}(72.2 \%)$ and SAC $(81.8 \%)$ reported that using their toilets was not convenient. The proportions 
were not significant as shown in Table 3 . In terms of privacy, $86 \%$ of the respondents said the level of privacy they felt when using the toilet was good (Figure 3). In terms of cleanliness, $46 \%$ of the respondents from $\mathrm{CH}, 50 \%$ from LC and all the respondents from SAC said their toilets were in good condition (Figure 4). However, comparison between wheelchair ramp availability and homes of the physically challenged person was not significant (Table 4).

\subsection{Challenges Faced by the Physically Challenged about the Use of Sanitation Facilities within Homes}

During the focus group discussions, the respondents expressed their views on the challenges they faced while using the toilet as regards balancing on the toilet seat. Some of the responses are shown below:

- "Personally I don't have any challenges.

- "Balancing on the toilet seat proves difficult for me" (FGD, Cheshire Home, males)
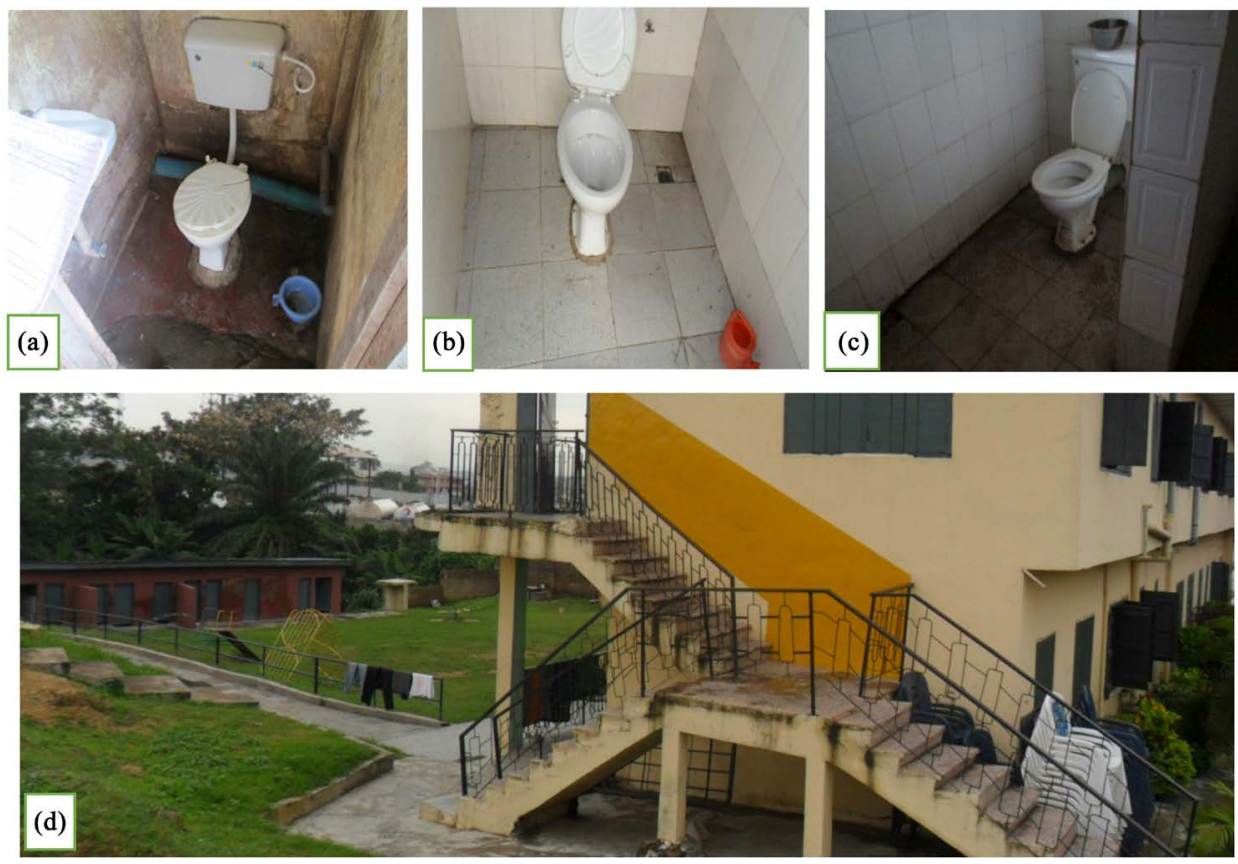

Figure 2. Accessible toilet facilities in the three homes without assistive devices for usage [(a) Toilet facility at Lawal Centre; (b) Male toilet facility in Sekinat Adekola Centre; (c) Male toilet facility in Cheshire Home; (d) Hostel].

Table 3. Comparison of convenience of the toilet structures and the home of physically challenged person.

\begin{tabular}{ccccc}
\hline \multirow{2}{*}{ Homes } & \multicolumn{3}{c}{ Convenience } & $\mathcal{X}_{\text {Fisher's Exact }}^{2}$ \\
\cline { 2 - 4 } & Not convenient (\%) & Convenient (\%) & Total & \\
\hline CH & $27(77.1)$ & $8(22.9)$ & 35 & \\
LC & $13(72.2)$ & $5(27.8)$ & 18 & $0.407(0.851)$ \\
SAC & $9(81.8)$ & $2(18.2)$ & 11 & \\
\hline
\end{tabular}




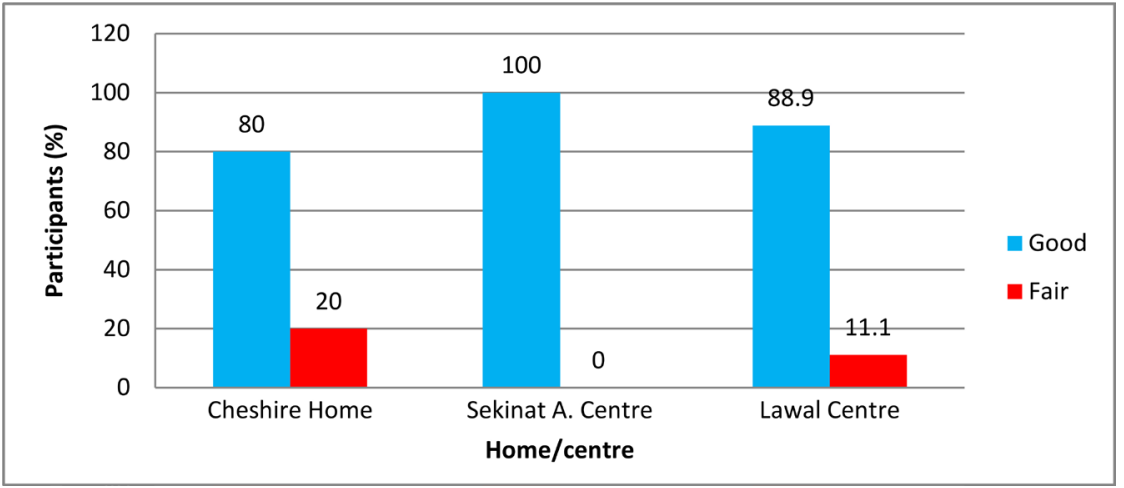

Figure 3. Participants' description of toilets in terms of privacy.

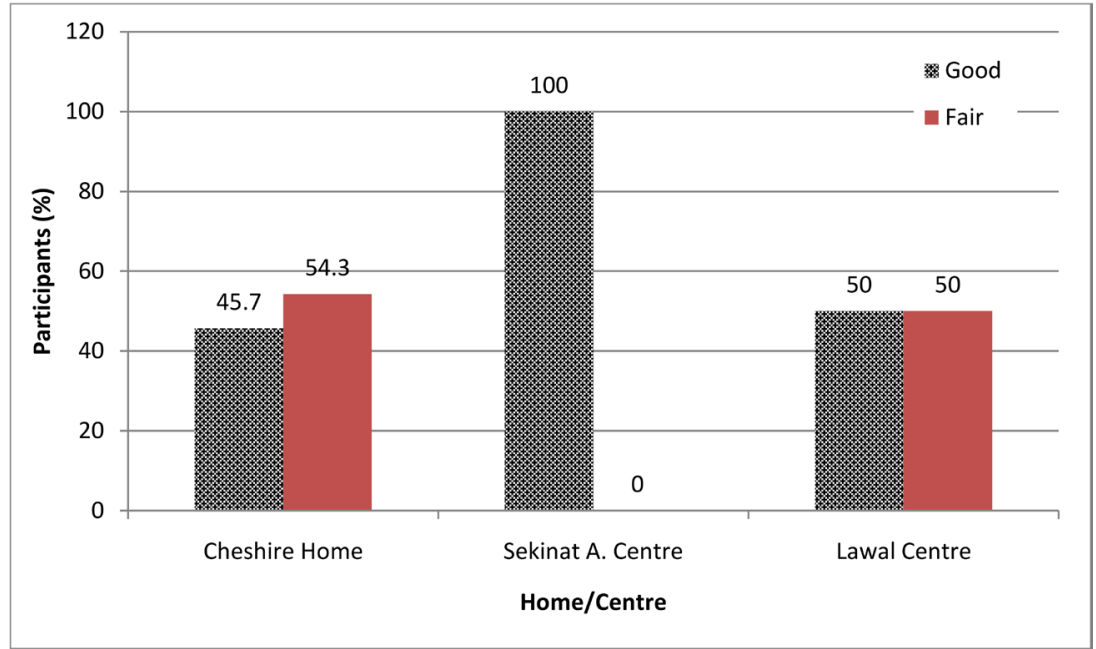

Figure 4. Participants' description of toilets in terms of cleanliness.

Table 4. Comparisons of wheelchair ramp availability and sex, home of the physically challenged person.

\begin{tabular}{ccccc}
\hline \multirow{2}{*}{ Characteristics } & \multicolumn{3}{c}{ Wheelchair ramp availability } & \multirow{2}{*}{$\chi_{\text {Fisher's Exact }}^{2}$ (p-Value) } \\
\cline { 2 - 4 } & Yes (\%) & No (\%) & Total (\%) & \\
Sex & & & & \\
Male & $8(22.2)$ & $28(77.8)$ & 36 & $6.779(0.017)$ \\
Female & $15(53.6)$ & $13(46.4)$ & 28 & \\
Homes & & & & \\
CH & $13(37.1)$ & $22(62.9)$ & 35 & $1.023(0.560)$ \\
LC & $5(27.8)$ & $13(72.2)$ & 18 & \\
SAC & $5(45.5)$ & $6(54.5)$ & 11 & \\
\hline
\end{tabular}

- "No challenge"

- "I find it hard to balance on the toilet seat so I make do with my potty". (FGD, Cheshire Home, females)

- "None, it is convenient for me"

- "With my potty, I don't have problems using the toilet" (FGD, Lawal Centre, males) 
- "I can't balance properly on the toilet seat" (FGD, Lawal Centre, females).

- "Getting down via the stairs is a great problem, so they should help us with our needs (wheel chair ramp)" (FGD, Sekinat Adekola Centre, females)

The respondents also expressed themselves in terms of the hygiene situation in their respective toilets. When asked if they were comfortable with their toilets in terms of cleanliness, they responded thus:

- "No, the care-giver is not consistent in cleaning the toilet. It is actually done randomly, like 2-3 times a week"

- "Water supply to the toilet is poor, we can't flush immediately after usage" (FGD, Cheshire Home, males)

- "Yes P m okay with it"

- "P m okay with it though regular water supply would be appreciated" (FGD, Cheshire Home, females)

- "We are not too comfortable. It can be cleaner than it is" (FGD, Lawal Centre, males)

- "The toilet needs cleaning, the floor is always dirty"

- "It is not too clean, at times we clean it ourselves" (FGD, Lawal Centre, females)

- "It is a neat and very comfortable place"

- "We need water for prompt cleaning" (FGD, Sekinat Adekola Centre, males).

- "Materials should be provided to clean the toilet"

- "The toilet downstairs is cleaner than the one upstairs but we can't go downstairs easily because we cannot use the stairs" (FGD, Sekinat Adekola Centre, females).

\subsection{Handwashing Practices}

Table 5 reveals that $81.2 \%$ of the respondents said they usually practiced handwashing with soap and water. Table 6 compares levels of handwashing practices across the homes. Handwashing practices scores were rated as poor $(0-10)$, fair $(11-15.5)$ and good $(15.6-20)$. The mean hygiene practice scores were not statistically significant $\left(\chi^{2}=4.28 \mathrm{p}=0.11\right)$.

Across the homes, the association between levels of education and handwashing levels was not significant (Tables 7-9). Similarly, Table 10 and Table 12 show that there was no significant association between the ages of the participants and their handwashing practices. However, there was a significant association between the ages of the respondents at Sekinat A. Centre and their handwashing practices (Table 11).

\section{Discussion}

The study documents the accessibility to sanitation facilities and handwashing 
Table 5. Reported handwashing practices.

\begin{tabular}{|c|c|c|c|c|c|}
\hline & & $\begin{array}{c}\text { C.H. } \\
\text { Freq. (\%) }\end{array}$ & $\begin{array}{c}\text { S.A.C } \\
\text { Freq. (\%) }\end{array}$ & $\begin{array}{c}\text { L.C. } \\
\text { Freq. (\%) }\end{array}$ & $\begin{array}{c}\text { Total } \\
\text { Freq. (\%) }\end{array}$ \\
\hline \multicolumn{6}{|c|}{ Regularity of bathing } \\
\hline Once a day & & $29(82.9)$ & $6(54.5)$ & $16(88.9)$ & $51(79.7)$ \\
\hline Twice a day ${ }^{*}$ & & $5(14.3)$ & $5(45.5)$ & $2(11.1)$ & $12(18.8)$ \\
\hline Thrice a day ${ }^{*}$ & & $1(2.9)$ & 0 & 0 & $1(1.5)$ \\
\hline Total & & $35(100)$ & $11(100)$ & $18(100)$ & $64(100)$ \\
\hline \multicolumn{6}{|c|}{ Items used for hand washing? } \\
\hline water only & & $10(28.6)$ & 0 & $2(11.1)$ & $12(18.8)$ \\
\hline water \& soap ${ }^{*}$ & & $25(71.4)$ & $11(100)$ & $16(88.9)$ & $52(81.2)$ \\
\hline Total & & $35(100)$ & $11(100)$ & $18(100)$ & $64(100)$ \\
\hline \multicolumn{6}{|c|}{ Soap availability for hand washing in the home } \\
\hline Always* & & $17(48.6)$ & $4(36.4)$ & $14(77.8)$ & $35(54.7)$ \\
\hline Sometimes & & $13(37.1)$ & $7(63.6)$ & $4(22.2)$ & $24(37.5)$ \\
\hline No, it is not & & $5(14.3)$ & 0 & 0 & $5(7.8)$ \\
\hline Total & & $35(100)$ & $11(100)$ & $18(100)$ & $64(100)$ \\
\hline \multicolumn{6}{|c|}{ Use of soap to wash hands when available } \\
\hline Always* & & $10(28.6)$ & $5(45.5)$ & $8(44.4)$ & $23(35.9)$ \\
\hline Sometimes & & $25(71.4)$ & $6(54.5)$ & $10(55.6)$ & $41(64.1)$ \\
\hline No, I do not & & 0 & 0 & 0 & 0 \\
\hline Total & & $35(100)$ & $11(100)$ & $18(100)$ & $64(100)$ \\
\hline \multicolumn{6}{|c|}{ Times soap is used for handwashing } \\
\hline \multirow[t]{2}{*}{ Before eating* } & Yes & $10(28.6)$ & $6(54.5)$ & $8(44.4)$ & $24(37.5)$ \\
\hline & No & $25(71.4)$ & $5(45.5)$ & $10(55.6)$ & $40(62.5)$ \\
\hline \multirow[t]{2}{*}{ After eating* } & Yes & $15(42.9)$ & $6(54.5)$ & $6(33.3)$ & $27(42.2)$ \\
\hline & No & $20(57.1)$ & $5(45.5)$ & $12(66.7)$ & $37(57.8)$ \\
\hline \multirow[t]{2}{*}{ After using the toilet* } & Yes & $27(77.1)$ & $10(90.9)$ & $17(94.4)$ & $54(84.4)$ \\
\hline & No & $8(22.9)$ & $1(9.1)$ & $1(5.6)$ & $10(15.6)$ \\
\hline After working/playing* & Yes & $35(100.0)$ & $11(100.0)$ & $17(94.4)$ & $63(98.4)$ \\
\hline No & & $0(0)$ & $0(0)$ & $1(5.6)$ & $1(1.6)$ \\
\hline
\end{tabular}

*good practice.

Table 6. Handwashing practice scores across the homes.

\begin{tabular}{ccccc}
\hline Hand washing Levels & $\begin{array}{c}\text { C.H. } \\
\text { Number (\%) }\end{array}$ & $\begin{array}{c}\text { S.A.C. } \\
\text { Number (\%) }\end{array}$ & $\begin{array}{c}\text { L.C. } \\
\text { Number (\%) }\end{array}$ & $\begin{array}{c}\text { Total } \\
\text { Number (\%) }\end{array}$ \\
\hline Fair handwashing practice & $22(62.9)$ & $3(27.3)$ & $10(55.6)$ & $35(54.7)$ \\
Good handwashing practice & $13(37.1)$ & $8(72.7)$ & $8(44.4)$ & $29(45.3)$ \\
Total & $35(100)$ & $11(100)$ & $18(100)$ & $64(100)$ \\
Mean Hygiene Practice Score & $15.4 \pm 1.9$ & $17.0 \pm 2.2$ & $16.4 \pm 2.3$ & $16.0 \pm 2.1$ \\
\hline$\chi^{2}=4.28, \mathrm{p}=0.11$. & & & &
\end{tabular}


Table 7. Association between Education and handwashing practices in Cheshire Home.

\begin{tabular}{ccccc}
\hline \multirow{2}{*}{ Hygiene Levels } & \multicolumn{3}{c}{ Levels of education } & Total \\
\cline { 2 - 4 } & $\begin{array}{c}\text { Primary } \\
\text { Freq. (\%) }\end{array}$ & $\begin{array}{c}\text { Secondary } \\
\text { Freq. (\%) }\end{array}$ & $\begin{array}{c}\text { Tertiary } \\
\text { Freq. (\%) }\end{array}$ & Freq. (\%) \\
\hline Fair Handwashing Practice $(11-15.5)$ & $1(25.0)$ & $15(65.2)$ & $6(75.0)$ & $22(62.9)$ \\
Good Hygiene Practice $(15.6-20)$ & $3(75.0)$ & $8(34.8)$ & $2(25.0)$ & $13(37.1)$ \\
Total & $4(100)$ & $23(100)$ & $8(100)$ & $35(100)$ \\
\hline
\end{tabular}

$\chi^{2}=3.01, \mathrm{p}=0.22$.

Table 8. Association between Education and handwashing practices in Sekinat A. Centre.

\begin{tabular}{ccccc}
\hline \multirow{2}{*}{ Hygiene Levels } & \multicolumn{3}{c}{ Levels of education } & \multirow{2}{*}{ Total } \\
\cline { 2 - 4 } & $\begin{array}{c}\text { Primary } \\
\text { Freq. (\%) }\end{array}$ & $\begin{array}{c}\text { Secondary } \\
\text { Freq. (\%) }\end{array}$ & $\begin{array}{c}\text { Tertiary } \\
\text { Freq. (\%) }\end{array}$ & Freq. (\%) \\
\hline Fair Handwashing Practice $(11-15.5)$ & $0(25.0)$ & $0(65.2)$ & $3(75.0)$ & $3(62.9)$ \\
Good Hygiene Practice $(15.6-20)$ & $1(75.0)$ & $2(34.8)$ & $5(25.0)$ & $8(37.1)$ \\
Total & $1(100.0)$ & $2(100)$ & $8(100)$ & $11(100)$ \\
\hline
\end{tabular}

$\chi 2=1.54, \mathrm{p}=0.46$

Table 9. Association between Education and handwashing practices in Lawal Centre.

\begin{tabular}{ccccc}
\hline \multirow{2}{*}{ Hygiene Levels } & \multicolumn{3}{c}{ Levels of education } & Total \\
\cline { 2 - 4 } & $\begin{array}{c}\text { Primary } \\
\text { Freq. (\%) }\end{array}$ & $\begin{array}{c}\text { Secondary } \\
\text { Freq. (\%) }\end{array}$ & $\begin{array}{c}\text { Tertiary } \\
\text { Freq. (\%) }\end{array}$ & Freq. (\%) \\
\hline Fair Handwashing Practice $(11-15.5)$ & $10(62.5)$ & $0(0)$ & $0(0)$ & $10(55.6)$ \\
Good Hygiene Practice $(15.6-20.0)$ & $6(37.5)$ & $1(100.0)$ & $1(100.0)$ & $8(44.4)$ \\
Total & $16(100.0)$ & $1(100)$ & $1(100)$ & $18(100)$ \\
\hline
\end{tabular}

$\chi^{2}=2.81, \mathrm{p}=0.24$

Table 10. Association between Age and handwashing practices in Cheshire Home.

\begin{tabular}{lccccccc}
\hline \multirow{2}{*}{ Hygiene Levels } & $\leq 15$ & $16-20$ & $21-25$ & $26-30$ & $\geq 35$ & Total \\
\cline { 2 - 7 } & Freq. (\%) & Freq. (\%) & Freq. (\%) & Freq. (\%) & Freq. (\%) & Freq. (\%) \\
\hline Fair Hygiene practice $(11-15.5)$ & $0(0)$ & $10(71.4)$ & $5(45.5)$ & $5(71.4)$ & $2(100)$ & $22(62.9)$ \\
Good Hygiene practice $(15.6-20)$ & $1(100.0)$ & $4(28.6)$ & $6(54.5)$ & $2(28.6)$ & $0(100)$ & $13(37.1)$ \\
Total & $1(100.0)$ & $14(100.0)$ & $11(100.0)$ & $7(100.0)$ & $2(100.0)$ & $35(100.0)$ \\
\hline$\chi^{2}=4.96, p=0.29$.
\end{tabular}

Table 11. Association between Age and handwashing practices in Sekinat A. Centre.

\begin{tabular}{|c|c|c|c|c|c|c|}
\hline \multirow[b]{2}{*}{ Hygiene Levels } & \multicolumn{6}{|c|}{ Age groups } \\
\hline & $\begin{array}{l}\quad \leq 15 \\
\text { Freq. (\%) }\end{array}$ & $\begin{array}{c}16-20 \\
\text { Freq. (\%) }\end{array}$ & $\begin{array}{c}21-25 \\
\text { Freq. (\%) }\end{array}$ & $\begin{array}{c}26-30 \\
\text { Freq. (\%) }\end{array}$ & $\begin{array}{c}\quad \geq 35 \\
\text { Freq. (\%) }\end{array}$ & $\begin{array}{c}\text { Total } \\
\text { Freq. (\%) }\end{array}$ \\
\hline Fair Hygiene practice $(11-15.5)$ & $0(0)$ & $0(0)$ & $0(0)$ & $3(100.0)$ & $0(0)$ & $3(27.3)$ \\
\hline Good Hygiene practice (15.6 - 20) & $2(100.0)$ & $2(100.0)$ & $2(100.0)$ & $0(0)$ & $2(100.0)$ & $8(72.7)$ \\
\hline Total & $2(100.0)$ & $2(100.0)$ & $2(100.0)$ & $3(100.0)$ & $2(100.0)$ & $11(100.0)$ \\
\hline
\end{tabular}


Table 12. Association between Age and handwashing practices in W.O. Lawal Centre.

\begin{tabular}{ccccc}
\hline \multirow{2}{*}{ Hygiene Levels } & \multicolumn{4}{c}{ Age groups } \\
\cline { 2 - 5 } & $\begin{array}{c}\mathbf{1} 15 \\
\text { Freq. (\%) }\end{array}$ & $\begin{array}{c}16-20 \\
\text { Freq.(\%) }\end{array}$ & $\begin{array}{c}\geq 35 \\
\text { Freq. (\%) }\end{array}$ & $\begin{array}{c}\text { Total } \\
\text { Freq. (\%) }\end{array}$ \\
\hline Fair Hygiene practice $(11-15.5)$ & $8(53.3)$ & $2(100.0)$ & $0(0)$ & $10(55.6)$ \\
Good Hygiene practice $(15.6-20)$ & $7(46.7)$ & $0(0)$ & $1(100.0)$ & $8(44.4)$ \\
Total & $15(100.0)$ & $2(100.0)$ & $1(100.0)$ & $18(100.0)$ \\
\hline
\end{tabular}

$\chi^{2}=2.88 ; \mathrm{p}=0.24$

practices among physically challenged persons in homes for the disabled in Ibadan, Nigeria. The sex ratio of the participants was 1.3 with the males slightly more than the females. A similar result was reported in a study on access to water, sanitation, and hygiene among people with disabilities in Mali [9]. All the physically challenged people had access to water closet toilet-type. This study found that a large proportion of the respondents spent about 4 minutes or less to get to the sanitation facility from their rooms, though few of them revealed that they spent up to 10 minutes to get to the toilet. This might be as a result of the long distance between their rooms and the toilet. In SAC, the toilet facility for the men (which was outside the hostel building) was $33 \mathrm{~m}$ from the hostel building; that is quite a long distance for a physically challenged individual with mobility impairment. Such an individual would experience so much discomfort in going to the toilet.

It was observed that there were no assistive devices to make toilet usage easier for the physically challenged people. Consequently, some of them complained of imbalance when using the toilet. They could fall and get hurt in the process. One very important fixed assistive device that aids the physically challenged in toilet usage is the handrail. Across the three homes (Cheshire Home, Sekinat Adekola Centre, and Lawal Centre), handrails were absent. This device provides the toilet users something to hold on to for balance while using the toilet. Though the ramp is not considered an assistive device, it aids the participants in moving around especially where there are steps to climb. In this study, there were ramps in all the homes though more ramps in more strategic positions would make movement and accessibility a whole lot easier; the females in Sekinat Adekola Centre need a wheelchair "ramp" in order to move up and down their hostel building with ease. Toilet facilities in homes for physically challenged people should be disabled-friendly to enhance usage by those they were made for. The study by Mahider and Priscilla [13], on people with HIV and disabilities in Ethiopia, reported similar findings which revealed that about half of the disabled people had access to latrines but found it difficult or impossible to use because of inappropriate designs. The study emphasized that children with disabilities were afraid of falling into poorly constructed latrines. Using a toilet facility that is not disabled friendly can be stressful to a physically challenged person. It also increases their chances of having infections as a result of the rigours they pass 
through before positioning themselves the right way in order to use the facility [14]. A briefing note on disability issues within water and sanitation service provision reported that women with mobility impairments still use bare hands at times when crawling inside the dirty sanitation facility [15]. Furthermore, though there were wheelchair ramps in some of the hostels, they were not enough in strategic positions, or where they were mostly needed, to aid movement around the homes for wheelchair users. A similar study conducted in Uganda by Kiwanuka [10] reported that for children using wheelchairs in a primary school, toilet access could be problematic because some of the latrines were located at a long distance from their hostel or home or class, and many do not have ramps.

The hygiene status of the toilets across the homes was not good enough. Some of the respondents crawled on the floor, thereby increasing the likelihood of coming down with diseases like cholera, typhoid, hepatitis, cryptosporidiosis, among others. Their reponses during the focus group discussion revealed that not all of them were impressed with the efforts of the caregivers in keeping the toilets clean. In Sekinat Adekola Centre, according to the females, the caregivers paid more attention to the toilets dwnstairs than the ones upstairs. The females had a toilet upstairs and two downstairs (which are not in the hostel building). In a situation whereby the one upstairs is occupied, access to the toilets downstairs was being denied by the fact that there was no wheelchair ramp to aid easy movement downstairs. These centres have to be built with the conditions of the inhabitants in mind for their health and well being. In Lawal centre, the hygiene status of the toilets were not good, as they were not properly flushed and the floor was not clean. Here, the effort of the caregivers was called into question; the physically challenged should not just be comfortable in their rooms alone, they should be comfortable in the toilet as well. Considering that some of the physically challenged crawl on the floor, when the toilet floor is not cleaned regularly, such persons are at a risk of getting infected, thereby worsening their condition.

Also, our observation revealed that the internal space of the toilets did not conform to the recommended dimensions. Variations were also observed across the homes and between male and female facilities within the same disabled home. This might negatively affect usage of the sanitation facility and limit access of the physically challenged people to toilets. A wheelchair user needs enough space in the toilet to go in and transition from the wheelchair to the toilet seat. Other studies have reported similar findings [8] [15].

Data from this study revealed that a high percentage of the respondents usually practiced handwashing with soap and water especially after using the toilet. However, only about half of the respondents reported that the handwashing materials were always available within reach. This is necessary since crawling and squatting exposes them to dirty materials, especially when entering toilets shared by many people. Often times using their hands for support without any 
available structure for balancing in the toilet could bring them into contact with urine and faeces [13]. It was only in Sekinat Adekola Centre for the Disabled that there was a significant association between age and hand washing practices. Thus, in Sekinat Adekola Centre, age could be said to influence the hand washing practices of the physically challenged persons.

\section{Conclusions}

This study showed that all the physically challenged persons in the study locations had access to water closet toilets. Most of the participants' practiced handwashing with water and soap, particularly after defecation. However, there were no assistive devices in the toilets (across the homes) to aid the physically challenged persons in toilet usage. Also, the toilet space did not conform to the standard measurement. There were variations in the toilet space dimensions across homes and within gender separated facilities. Some of the toilets were not clean enough for physically challenged people, particularly for those that might in one way or the other use their hands for support during movement. This apparently emphasized that the caregivers were not consistent with their duties of keeping the toilets clean.

The study recommends that sanitation facilities in homes for disabled persons and other public places should be appropriately built with assistive devices to make them disabled-friendly and maintained in a hygienic manner to avoid the risk of sanitation-related diseases. This implies that management of the homes should ensure a constant supply of water for maintenance of good hygiene practices and status of the sanitation fcilities; also committed caregivers (2 males and 2 females) should be employed to look after the physically challenged persons.

\section{Acknowledgements}

The authors appreciate the support of the participants, and research assistants in ensuring the completeness of this study. The independent reviewers are also appreciated.

\section{Conflicts of Interest}

The authors declare no conflicts of interest regarding the publication of this paper.

\section{References}

[1] Jones, H.E. and Reed, R.A. (2005) Water and Sanitation for Disabled People and Other Vulnerable Groups: Designing Services to Improve Accessibility. WEDC, Loughborough University, United Kingdom.

[2] Lang, R. and Upah, L. (2008) Scoping Study: Disability Issues in Nigeria. Final Report Commissioned by DFID April 2008.

https://studylib.net/doc/13390397/scoping-study--disability-issues-in-nigeria-finalreport 
[3] National Population Commission (NPC) [Nigeria] and ICF. (2019) Nigeria Demographic and Health Survey, 2018. Abuja, Nigeria, and Rockville, Maryland, USA: NPC and ICF.

[4] WHO/UNICEF/WSSCC. Sanitation Matters! Celebrating World Water Day 2008. (2008) Updated Version of the WHO Advocacy Guide for Water for life. Annex: 10 Things You Need to Know about Sanitation: 9. https://www.who.int/water_sanitation_health/hygiene/iys/wwd_2008.pdf

[5] World Health Organization (WHO) and the United Nations Children's Fund (UNICEF) (2017) Progress on Drinking Water, Sanitation and Hygiene: 2017 Update and SDG Baselines. Geneva: License CC BY-NC-SA 3.0 IGO.

http://apps.who.int/iris/bitstream/handle/10665/258617/9789241512893-eng.pdf;jse ssionid=0AE0EAECA545A5B4CDD4630D80F371D9? sequence $=1$

[6] Akhidenor, C.D. (2007) Nigerians' Attitudes towards People with Disabilities. Dissertation, Capella University.

http://citeseerx.ist.psu.edu/viewdoc/download?doi=10.1.1.518.8859\&rep=rep1\&type $=\mathrm{pdf}$

[7] Tobis, D. (2000) Moving from Residential Institutions to Community-Based Social Services in Central and Eastern Europe and the Former Soviet Union (English). A World Free of Poverty series. Washington DC: The World Bank.

http://documents.worldbank.org/curated/en/738301468768587459/Moving-from-reside ntial-institutions-to-community-based-social-services-in-Central-and-Eastern-Europe-a nd-the-former-Soviet-Union https://doi.org/10.1596/0-8213-4490-0

[8] Sachelo, C. (2002) Questionnaire Response. Executive Director, Zambia National Association of the Physically Handicapped: Ndola, Zambia.

[9] Tan, K.S., Norman, W.R., Knepper, S. and Kamban, N. (2019) Access to Water, Sanitation and Hygiene: A Survey Assessment of Persons with Disabilities in Rural Mali”. figshare. https://hdl.handle.net/2134/30973

[10] Kiwanuka, M. (2002) Response to Research Questionnaire. Occupational Therapist, Community Based Rehabilitation Alliance (COMBRA), Uganda.

[11] Nigeria Demographics Profile. (2018) Central Intelligence Agency (CIA). World Fact Book, 2002.

[12] Udofia, I.P. and Oloruntoba, E.O. (2019) Potable Water Supply among the Physically Challenged in Selected Homes for the Disabled in Ibadan. Journal of Water, Sanitation and Hygiene for Development, 9, 225-236.

[13] Tesfu, M. and Priscilla, M. (2008) Equal Access for All? Issues for People with HIV and with Disabilities in Ethiopia. Water Aid Ethiopia, Ethiopia. Proceedings of 33 rd WEDC International Conference, Accra, Ghana.

[14] Pradhan, A. and Jones, O. (2008) Creating User-Friendly Water and Sanitation Services for the Disabled: The Experience of Water Aid Nepal and Its Partners.

[15] Jones, H. and Fisher, J. (2005) Why Should Water and Sanitation Consider Disabled People? WELL Briefing Note 12. WEDC, Loughborough University, Leicestershire. 